\title{
Concentrations of Anthraquinone Glycosides of Rumex crispus during Different Vegetation Stages
}

\author{
L. Ömür Demirezer \\ Hacettepe University, Faculty of Pharmacy, Department of Pharmacognosy, \\ 06100 Ankara, Turkey \\ Z. Naturforsch. 49 c, 404-406 (1994); received January 31, 1994 \\ Rumex crispus, Polygonaceae, Anthraquinone, Glycoside \\ The anthraquinone glycoside contents of various parts of Rumex crispus L. (Polygonaceae) \\ in different vegetation stages were investigated by thin layer chromatographic and spectro- \\ photometric methods. The data showed that the percentage of anthraquinone glycoside in \\ all parts of plant increased at each stage. Anthraquinone glycoside content was increased in \\ leaf, stem, fruit and root from 0.05 to $0.40 \%$, from 0.03 to $0.46 \%$, from 0.08 to $0.34 \%$, and \\ from 0.35 to $0.91 \%$ respectively. From the roots of $R$. crispus, emodin- 8 -glucoside, RGA \\ (isolated in our laboratory, its structure was not elucidated), traceable amount of glucofran- \\ gulin $\mathrm{B}$ and an unknown glycoside $\left(R_{\mathrm{f}}=0.28\right.$ in ethyl acetate: methanol: water/100:20:10) \\ was detected in which the concentration was increased from May to August. The other parts \\ of plant contained only emodin-8-glucoside.
}

\section{Introduction}

Rumex L. (Polygonaceae) is one of several genera which is characterized by the presence of anthraquinone derivatives. There are about 200 species of Rumex in worldwide (Hegi, 1957). Rumex is represented with 23 species and 5 hybrids in Turkey (Davis, 1965) and their roots have important traditional uses according to their laxative properties. For instance, infusions prepared from the underground parts have been claimed to be therapeutically useful as diuretic, cholagogue, tonic and laxative (Baytop, 1984).

Chemical studies have been carried out on the aerial and underground parts of the plant. Anthraquinone glycoside amount of $R$. crispus has given for underground part $0.52 \%$ and for aerial part $0.44 \%$ (Sener et al., 1987). In the same study, it has been determined that, $R$. crispus contained emodin chrysophanol and physcion. On the other hand, in a different study described, a period from germination to ripening stages has been investigated in $R$. hydrolapathum roots and it has been established that, first emodin, physcion and chrysophanol anthrons and then chrysophanol, physcion have been formed. The final product has been detected as emodin. But no information has been obtained on the effects of seasonal changes on the content of anthraquinone glycosides of leaves, stems, fruits and roots (Labadie et al., 1972).
In the present investigation various parts of Rumex crispus, leaf, stem, fruit and root were analyzed separately for their anthraquinone glycoside contents, the glycosides in different vegetation stages were detected individually. By this method, translocation of anthraquinone glycosides were also investigated.

\section{Materials and Methods}

Rumex crispus samples were collected per individual from May 15, 1993 to August 30, 1993 from Ankara. The plants under study were authenticated by reference to herbarium specimens at the Ankara Fen Fakültesi, Ankara, Turkey. Completely dried materials were separated to root, stem, leaves and fruits and powdered with an electric grinder. Extracts from the roots were obtained by the method given in Pharmacopeia (DAB 9). Accurately weighed samples were heated with $70 \%$ methanol for 15 min under reflux and extracted three times with diethylether. The aqueous extracts were heated with $20 \%$ ferrichloride for $20 \mathrm{~min}$ under reflux and afterwards $\mathrm{HCl}$ was added, heated for $20 \mathrm{~min}$ and then the mixture was transferred to a separating funnel and extracted with three quantities of diethylether. The absorbance was measured at $515 \mathrm{~nm}$ for all anthraquinone glycosides. All samples have been analyzed in triplicates. 


\section{Thin layer chromatography}

Test solution: $0.25 \mathrm{~g}$ of the powdered drug were suspended in $3 \mathrm{ml}$ methanol and heated to boiling. The extract was filtrated at room temperature and $10 \mu \mathrm{l}$ were applied to a silica gel plate on a line $15 \mathrm{~mm}$ long. TLC was developed using a mixture of ethyl acetate: methanol: water $(100: 20: 10)$. Extracts were also applied to RP-18 plate and developed with $70 \%$ methanol. TLCs were sprayed with $\mathrm{KOH}(5 \%$ in methanol) and heating for $15 \mathrm{~min}$ at $100^{\circ} \mathrm{C}$. The chromatograms of the test solution showed several red zones. Glucofrangulin A 2,3-diacetate, glucofrangulin A 2,4-diacetate, glucofrangulin A 3,4-diacetate, frangulin C (Demirezer, 1991), frangulin $\mathrm{A}$ and $\mathrm{B}$, emodin-8-glucoside, physcion-8-glucoside, aloin, glucofrangulin A and $\mathrm{B}, \mathrm{RGA}$ (isolated in our laboratory but its structure not elucidated yet) were used as reference substances.

\section{Results and Discussion}

Anthraquinone glycoside content was determined in Rumex crispus in all parts of plant separately in different vegetation stages. This study was completed within four months from mid-May to the end of August. The highest anthraquinone glycoside content was established in the roots of $R$. crispus during vegetation stages $(0.35-0.91 \%)$ while the stem from 0.03 to $0.46 \%$, leaves from
Table I. Amount of anthraquinone glycoside in Rumex crispus root during the vegetation period.

\begin{tabular}{lllll}
\hline \multirow{2}{*}{ Months } & \multicolumn{4}{c}{ Anthraquinone $[\%$ of dry weight] } \\
& Roots & Stems & Leaves & Fruits \\
\hline May & 0.35 & 0.03 & 0.05 & 0.08 \\
June & 0.40 & 0.10 & 0.14 & 0.16 \\
July & 0.33 & 0.30 & 0.39 & 0.08 \\
August & 0.91 & 0.46 & 0.40 & 0.34 \\
\hline
\end{tabular}

0.05 to $0.40 \%$ and the fruits from 0.08 to $0.34 \%$ reached (Table $\mathrm{I}$ ). It is evident from the data, that all parts of plant showed the highest anthraquinone glycoside content in August. By July, the leaves had nearly reached their final size. At this stage of leaf development, quite high anthraquinone glycoside content was determined $(0.39 \%)$. This value reached highest in August $(0.40 \%)$. In a previous study on $R$. hydrolapathum fruits, the occurrence of anthracene derivatives could not be ascertained (Labadie et al., 1972). According to our findings $R$. crispus fruits, contained anthraquinone glycoside in all vegetation stages. Approximately two days after flowering, very small pods were appeared which grew later. During this period (from May to July) anthraquinone glycoside content was low in the fruits. The pods turned from green to brown and remarkable increase in anthraquinone glycoside content was observed from 0.08 to $0.34 \%$ in August. According to the data obtained, significant changes were detected

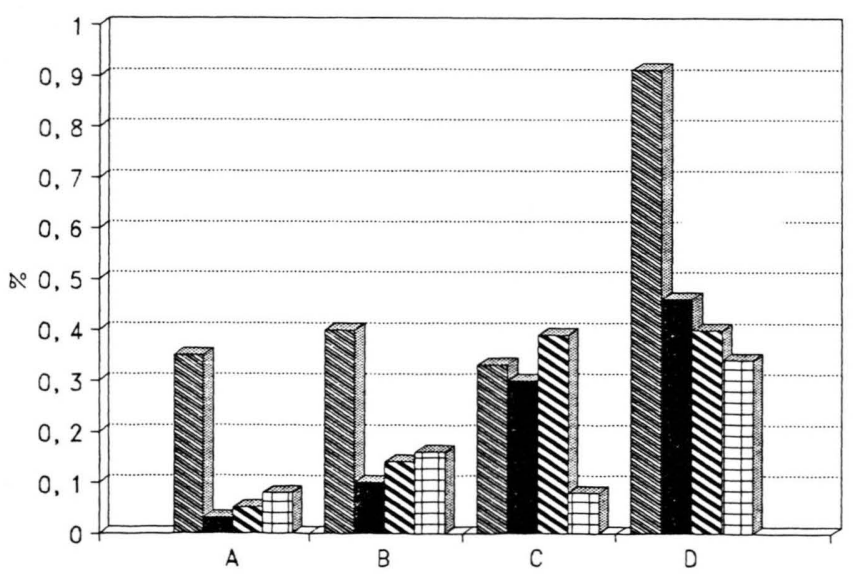

ROOTS STEMS $\mathbf{N}$ LEAVES FRUITS
Fig. 1. Comparison of all parts of Rumex crispus during vegetation period. A: May; B: June; C: July; D: August. 
in the percentage of these substances in all parts of $R$. crispus from the beginning to end (Fig. 1). Fig. 1 showed the content of anthraquinone glycosides in all parts of the plant for each month. It was clearly seen that the anthraquinone glycoside content of the roots of the plant was significantly high in each month but highest in August. However, in July the results of roots, stem and leaves were very similar. From the point of the content of anthraquinone glycoside, our findings showed that the favourable harvest time is August. At the beginning of this study, we planned the translocation of anthraquinone glycosides from roots to fruits. But no translocation were proved. According to our results obtained, right from the beginning of vegetation there was an accumulation of anthraquinone glycosides in all parts of plant.

On the other hand, the occurrence of such emodin derivatives in Rumex was as predicted. In the roots of Rumex crispus during vegetation period emodin-8-glucoside, RGA, traceable amount of glucofrangulin $\mathrm{B}$ and an unknown anthraquinone glycoside $\left(R_{\mathrm{f}}=0.28\right.$ in ethyl acetate: Meth-

Baytop T. (1984), Türkiye'de Bitkilerle Tedavi (Geçmiste ve Bugün). Sanat Matbaasi, Istanbul.

Davis P.-H. (1965), Flora of Turkey. University Press, Edinburgh.

Demirezer L. Ö. (1991), Glukofrangulinanthrone A/B, deren Oxidationsformen und davon abgeleitete Zukkerester aus Rhamnus-Arten: Beiträge zur chemischanalytischen und physiologischen Kennzeichnung. Dissertation, Frankfurt/M.

Fassil Y., Bezabeh A. and Abegaz B. (1985), Anthracene derivatives from Rumex abyssinicus. J. Natl. Prod. 48 (1), 148.

Hegi G. (1957), Illustrierte Flora von Mitteleuropa, Band III (1). Carl Hanser Verlag, München. anol:water/100:20:10) was detected in increasing concentrations. Leaves, stem and fruits contained only emodin-8-glucoside. By our preliminary examination we have isolated an anthraquinone glycoside, RGA, which has an aloe-emodin aglycone and its exact structural elucidation is under investigation. Until now, in Rumex species even the chrysophanol-8-glucoside, physcion-1-glucoside and physcion-8-glucoside were found (Fassil et al., 1985; Kato et al., 1987) but none of the aloeemodin glycoside obtained.

In conclusion: The natural anthraquinone derivatives which are generally considered to be as secondary natural products were determined to be present in the very first stages of development. This group of compounds should play an important role in the metabolism of the plant. Secondly, the concentration of the glycoside mixtures were highest in the roots. Thirdly, Rumex crispus contained not only emodin, chrysophanol and physcion glycoside but also aloe-emodin glycoside.

Kato T. and Morita Y. (1987), Anthraquinone components in Rumex acetosa L. Shoyakugaku Zasshi 41 (1), $67-74$.

Labadie R. P., Otten J. and Svendsen Baerheim A. (1972), An investigation on the anthracene derivatives in Rumex hydrolapathum Huds. (I). Pharm. Weekbl. $107,547$.

Sener B., Basgül M., Akar F. and Kanzik I. (1987), Türkiye'de Yetisen Bazi Rumex L. Türlerinin Antrakinon Türevi Bilesikler Yönünden Karsilastirilmasi. Proc. of the VIth Symposium on Plant Originated Crude Drugs (B. Sener, ed.), G. Ü. Basin-Yayin Yüksek Okulu Matbaasi, Ankara, pp. 345-350. 